\title{
A SIMPLE SYSTEM OF FORWARD BATTLE ANAESTHESIA
}

\author{
Lieutenant-Colonel D. I. MACNAIR, \\ M.B., B.S., F.F.A.R.C.S., D.A., R.A.M.C. \\ Military Hospital, Catterick
}

SUMMARY: Recently 5 Field Surgical Team (F.S.T.) of 23 Parachute Field Ambulance R.A.M.C. had the opportunity to put into practice some aspects of its professional training. This article describes the anaesthetic sequence and includes comments on it from the viewpoint of the forward anaesthetist, and particularly of one delivered to the battle ground below a parachute.

\section{Introduction}

Details of the surgical load are given in Table I. All but 7 patients were adults

Table I

Distribution of surgical material

\begin{tabular}{|c|c|c|}
\hline \multirow{2}{*}{ Operation } & \multicolumn{2}{|c|}{ Patients } \\
\hline & Adult & Child \\
\hline $\begin{array}{l}\text { Laparotomy for acute appendicitis } \\
\text { Craniotomy for gun shot wound } \\
\text { Thoracotomy for gun shot wound } \\
\text { Thoraco-abdominal exploration for gun shot wound } \\
\text { Laparotomy for gun shot wound } \\
\text { Debridement for solitary gun shot wound } \\
\text { Debridement for multiple gun shot wounds } \\
\text { Amputations for gun shot wounds } \\
\text { Delayed primary suture for solitary gun shot wound } \\
\text { Delayed primary suture for multiple gun shot wounds } \\
\text { Primary suture of gun shot wounds of hand } \\
\text { Split skin graft }\end{array}$ & $\begin{array}{r}6 \\
1 \\
1 \\
2 \\
37 \\
11 \\
5 \\
27 \\
8 \\
1\end{array}$ & $\begin{array}{l}1 \\
2 \\
2\end{array}$ \\
\hline Totals & 99 & 7 \\
\hline
\end{tabular}

and of these 78 were military personnel and 21 were civilians. The range of surgery was wide with the expected preponderance of limb injuries. The term Gun Shot Wound (G.S.W.) is used here to include both high and low velocity missile injuries. There were two deaths during surgery, neither coming as a surprise in view of the extent of the injuries. The discrepancy between the number of debridements and Delayed Primary Suture (D.P.S.) is explained by the rearwards evacuation of some patients during the 5 day interval between the procedures. The number of appendicectomies underlines the continuing presence of commonplace surgical pathology in any situation.

Table II shows the quantity of agents used, in terms of ampoules, bottles and vials. The column for halothane merely shows the number of patients receiving the agent and not shown is that 18 bottles were consumed. A bottle of halothane contains $250 \mathrm{ml}$ and the rate of consumption was thus approximately one per 5 patients, or an average of $45 \mathrm{ml}$ per patient. In 5 cases, all of solitary upper limb injury, brachial plexus block was performed and general anaesthetic avoided. Diazepam alone was used in a further two cases for short procedures. 
Table II

Quantities of anaesthetic agents consumed

\begin{tabular}{|c|c|c|c|c|c|c|c|c|c|c|c|c|c|c|c|}
\hline \multirow{2}{*}{$\begin{array}{c}\text { Agents (in ampules/ } \\
\text { bottles/vials }\end{array}$} & \multicolumn{14}{|c|}{ Distribution of agents to 106 patients } & \multirow{2}{*}{ Totals } \\
\hline & 2 & 2 & 1 & 2 & 7 & 3 & 2 & 16 & 4 & 4 & 19 & 10 & 32 & 2 & \\
\hline $\begin{array}{l}\text { Marcaine } \\
\text { Lignocaine } \\
\text { Atropine } \\
\text { Thiopentone } \\
\text { Diazepam } \\
\text { Halothane } \\
\text { Brevidil M } \\
\text { Gallamine } \\
\text { Atropine } \\
\text { Neostigmine }\end{array}$ & 2 & 6 & 2 & 2 & 7 & $\begin{array}{l}3 \\
3\end{array}$ & $\begin{array}{l}2 \\
2 \\
2 \\
2\end{array}$ & $\begin{array}{l}16 \\
16 \\
16 \\
16\end{array}$ & $\begin{array}{l}4 \\
4 \\
4\end{array}$ & $\begin{array}{l}4 \\
4 \\
4 \\
4 \\
4\end{array}$ & $\begin{array}{l}19 \\
19\end{array}$ & $\begin{array}{l}10 \\
10\end{array}$ & $\begin{array}{l}64 \\
32\end{array}$ & $\begin{array}{l}6 \\
2\end{array}$ & $\begin{array}{r}8 \\
2 \\
29 \\
40 \\
90 \\
99 \\
24 \\
12 \\
11 \\
11\end{array}$ \\
\hline
\end{tabular}

Six cases had received morphine prior to admission to the F.S.T., but no other patient was given any pre-operative drug except tetanus toxoid and antibiotic. Casualties for intubation received atropine $0.6 \mathrm{mg}$ at induction but otherwise this agent was neither deemed necessary, nor given. Seven patients, all children, had an inhalation induction and the remaining 92 an intravenous one - the first 52 with thiopentone and the remaining 40 with diazepam. Maintenance was in all cases by halothane in air from a simple draw-over vaporiser. This consisted of a 6 ounce screw-top jar of domestic origin containing the halothane and a 3 foot length of anaesthetic tubing leading to an Ambu valve and a face-mask. When Intermittent positive pressure respiration (I.P.P.R.) was undertaken a Laerdahl bag was inserted between the vaporiser and the patient. Immediately distal to the vaporiser was a 6 inch length of aluminium tubing of 1 inch diameter (cannibalised from a defunct petrol pump) with a lateral orifice of the same diameter. A simple sliding rubber cuff outside the orifice allowed the inhaled vapour to be approximately halved, as a proportion of the inhaled air was not then drawn over halothane. The entire apparatus, together with the necessary connectors, endotracheal tubes, laryngoscope and accessories, weighed $2 \mathrm{~kg}$. When intubation was performed Brevidil $\mathrm{M}$ was used and when a non-depolarising relaxant was indicated gallamine was given, its effect being reversed in the usual manner with atropine and neostigmine.

\section{Comments}

The simple anaesthetic apparatus and the small range of agents were deliberately chosen although a Haloxair apparatus and more agents were available. The reason for this was that the situation afforded the opportunity to test light scales under field conditions over an extended period of time. These criteria are particularly significant in the parachute assault phase of an airborne operation when the members of an F.S.T. have to carry, literally on their backs, the wherewithal for immediate surgery of any type. Only when heavy-drop supplies have been received and a formal surgical centre set up does more sophisticated apparatus become available. The writer does not claim that the anaesthetic technique using such simple drugs and apparatus is ideal, but that it is feasible. Indeed, in the early phases of an airborne operation there seems nothing to challenge it for simplicity, versatility and safety. 
Quantities of drugs are given in Table III which, under advanced surgical conditions,

Table III

Suggested quantities of agents for ten patients

\begin{tabular}{l|l|c}
\hline \multicolumn{1}{c|}{ Quantity } & \multicolumn{1}{|c|}{ Agent } & Weight (Grammes) \\
\hline 4 boxes of 5 ampoules & Diazepam (10 mg ampoules) & 200 \\
1 box of 10 ampoules & Gallamine (120 mg ampoules) & 100 \\
2 boxes of 10 ampoules & Atropine (0.6 mg ampoules) & 90 \\
1 box of 10 ampoules & Neostigmine (2.5 mg ampoules) & 45 \\
1 box of 10 ampoules & Brevidil M (67 mg ampoules) & 100 \\
1 box of 10 ampoules & Nalorphine (10 mg ampoules) & 35 \\
2 bottles of $250 \mathrm{ml}$ & Halothane (250 ml) & 850 \\
1 box of 10 ampoules & Water for injections & 150 \\
\hline Total weight & & 1570 \\
\hline
\end{tabular}

could be regarded as an adequate requirement for an initial 10 patients under any conditions. The total load, including the apparatus as described, is around $3.5 \mathrm{~kg}$.

Table IV compares the logistics of three possible induction agents for 10 patients.

Table IV

Logistics of agents sufficient for induction of 10 patients

\begin{tabular}{l|c|c}
\hline \multicolumn{1}{c|}{ Agent } & Space occupied $\left(\mathrm{cm}^{3}\right)$ & Weight (Grammes) \\
\hline Intraval sodium & 2000 & 600 \\
Pentothal sodium multidose & 1070 & 600 \\
Diazepam & 470 & 200 \\
\hline
\end{tabular}

The multidose preparation of thiopentone 2.5 per cent occupies half the space of the single ampoule preparation of the same agent and weighs much the same. Diazepam, in contrast, occupies less than half the space of the multidose preparation and weighs only a third as much. A further logistic advantage in that diazepam can be injected from $5 \mathrm{ml}$ syringes whereas thiopentone requires $20 \mathrm{ml}$ ones.

Logistics apart, diazepam has certain advantages over thiopentone. It produces negligible cardiovascular or respiratory depression but a marked anterograde amnesia. The writer was somewhat unnerved at first to find patients making apparently purposive movements of protest during intubation, but no patient recalled the event. All patients recovered consciousness rapidly after operation, whether they received thiopentone or diazepam. The writer attributes this, and the lack of postoperative vomiting, to the absence of morphine or pethidine as premedicant and to the absence of nitrous oxide from the anaesthetic sequence. There would seem to be two possible objections to diazepam. Firstly, that it is uncertain how much of the agent may be required to induce a given patient. Secondly, that patients are slowly induced. The writer's experience with the newly introduced steroid Althesin, and perusal of the recent literature, suggest to him that the latter might well be preferable to diazepam. Logistically, there is nothing to choose between the drugs and it is certainly easier to calculate a reliable induction dose of Althesin. 
Although local analgesics are sometimes advocated for the forward surgical situation, there were in this series few patients whose injuries, by their nature and distribution, did not preclude the use of local analgesia. There were only two cases for whom Ketamine alone would have seemed a feasible agent and the writer finds no indication for this agent in the armamentarium of the forward anaesthetist.

\section{Acknowledgement}

The writer is pleased to acknowledge the stimulus given to him by Major T. B. Boulton, E.R.D., M.B., F.F.A.R.C.S. (T.A.V.R.) to learn and then to apply the technique described in this paper.

\section{ACADEMIC ACHIEVEMENTS}

M.D.(Ed.) - MaJor-General H. C. JefFReY, Q.H.S., F.R.C.P.(ed.), F.R.C.Path., D.T.M.\&H.,

M.A.(Dub.)

F.R.C.S.(Eng.)

F.R.C.S.(Eng.)

(In Otolaryngology)

F.R.C.S.(Ed.)

F.R.C.S.(Glas.)

M.R.C.Psych.

M.F.C.M.

M.R.C.G.P.

M.R.C.O.G. D.Obs.R.C.O.G.

D.P.M.

D.P.H. Late R.A.M.C.

Captain A. G. Youell, M.B., Ch.B., R.A.M.C.

Captain R. C. Volkers, M.B., B.S., M.R.C.S., L.R.C.P., R.A.M.C.

MAJOR K. B. HugheS, M.B., B.S., M.R.C.S., L.R.C.P., D.L.o., R.A.M.C.

Major M. Pinder, M.B., Ch.B., R.A.M.c. Captain M. Sutton, M.A., B.M., B.ch., R.A.M.C.

MAJOR G. L. FoWKES, M.B., B.S., R.A.M.C.

Captain I. D. Plant, M.B., Ch.B., D.P.M., R.A.M.C.

Brigadier J. E. MILLER, M.C., Q.H.S., M.R.C.S., L.R.C.P. Late R.A.M.C. LIEUTIENANTColonel T. M. Goodall, O.B.E., M.B., Ch.B., R.A.M.C. Lifutenant-Colonel D. C. WEEKS, M.B., Ch.B., D.T.M.\&H., R.A.M.C.

Lieutenant-Colonel J. D. Bell, M.B., ch.B., B.A.O., D.T.M.\&H., D.C.H., R.A.M.C. Lieutenant-Colonel A. O. BIllinghurst, M.B., B.S., R.A.M.C. MAjor A. J. Warsap, M.A., B.M., B.Ch., R.A.M.C. Captain E. J. M. Cantillon, M.B., B.ch., B.A.O., R.A.M.C.

MAJOR C. R. FLINDELL, M.B., B.S., M.R.C.S., L.R.C.P., D.obst.R.C.O.G., R.A.M.C.

Major J. N. GILkison, M.B., ch.B., R.A.M.C. MajoR P. F. LUTTER, M.B., B.s., R.A.M.C.

MAJOR J. R. BIRD, M.B., B.S., M.R.C.S., L.R.C.P., R.A.M.C.

MAJOR K. W. WOOLHEAD, L.M.S.S.A., D.T.M.\&H., R.A.M.C. 